\title{
COMMENTARY
}

\section{Sepsis after Scotland: enough with the averages, show us the effect modifiers}

\author{
Theodore J Iwashyna*1-3 and Andrew J Odden ${ }^{1,4}$ \\ See related research by Cuthbertson et al., http://ccforum.com/content/17/2/R70
}

\begin{abstract}
Cuthbertson and colleagues demonstrate that survivors of severe sepsis face, in general continued ongoing high mortality and quite poor quality of life. This cohort caps the initial, problem-definition stage on long-term outcomes after critical illness. Having compellingly demonstrated the opportunities for improvements in outcomes, epidemiologic and behavioral research must now to turn to understanding the mechanisms by which these outcomes can be improved. Such fundamental research will provide the evidence base to drive informed and successful interventional trials.
\end{abstract}

In the previous issue of Critical Care, Cuthbertson and colleagues [1] capped a long-standing research agenda by reporting long-term mortality and quality of life among survivors of severe sepsis from a Scottish cohort. These sepsis-specific data from a large population catchment are a nice complement to the previous important work done in a related cohort [2]. The overall story that has emerged is fascinating, congruent, and yet incomplete.

On average, life after critical illness is hard. The average quality of life of patients after sepsis is quite low in Scotland and Scandinavia $[1,2]$. It is low on average after acute respiratory distress syndrome in Toronto [3]. Patients with sepsis have increased average mortality for many years in Scotland as they do in the US, both in the Department of Veterans Affairs [4] and in populationbased data for the over-65 population [5]. While high pre-sepsis burden of illness certainly sets the stage for these problems [6-8], many of these problems are new with severe sepsis.

\footnotetext{
*Correspondence: tiwashyn@umich.edu
}

'Department of Internal Medicine, University of Michigan, North Campus Research Center, 2800 Plymouth Road, Building 16, Room 332W, Ann Arbor, MI 48109, USA Full list of author information is available at the end of the article
Such findings can seem bleak and lead to an easy nihilism about the futility of intensive care unit care. Our patients seem to think otherwise. One hundred percent of the Scottish survivors - the same folks with all those problems - say they would go through intensive care again [1]. This suggests that we are at a critical intellectual turning point in the field. We have clearly defined that there is a litany of adverse outcomes among survivors of critical illness. We have not yet discovered how to make this better.

The need here is not merely for additional clinical trials. New clinical trials are unlikely to succeed until we have additional rigorous epidemiologic and behavioral research to understand the mechanisms by which some patients do better and other patients do worse.

Specifically, we desperately need to understand the effect modifiers of the disablement process as it leads to key long-term outcomes after critical illness. Figure 1 presents the disablement process model [9], modified to explicitly consider an acute disruption [10-12]. Baseline status - composed of a patient's physiology, activity limitations (difficulty performing standardized tasks in standardized environments such as 6-minute walks), and social disability (difficulty participating in social roles in one's usual environment) - is influenced by an acute insult, such as severe sepsis, sequentially leading to tissue pathology, activity limitations, and participation restrictions. The Scottish group goes even further, extending the process to quality of life.

Clinical practice has long taught us that there is no linear correlation between different steps of the disablement process. Neither ejection fraction nor FEV1 (forced expiratory volume in 1 second) is sufficient to explain which patients with heart failure or chronic obstructive pulmonary disease will be debilitated; although both play a role, clearly there are other factors that influence the development and magnitude of disability.

Current research to date has defined this new problem space and demonstrated this problem's population impact along the main tissue pathology/activity limitations/ 


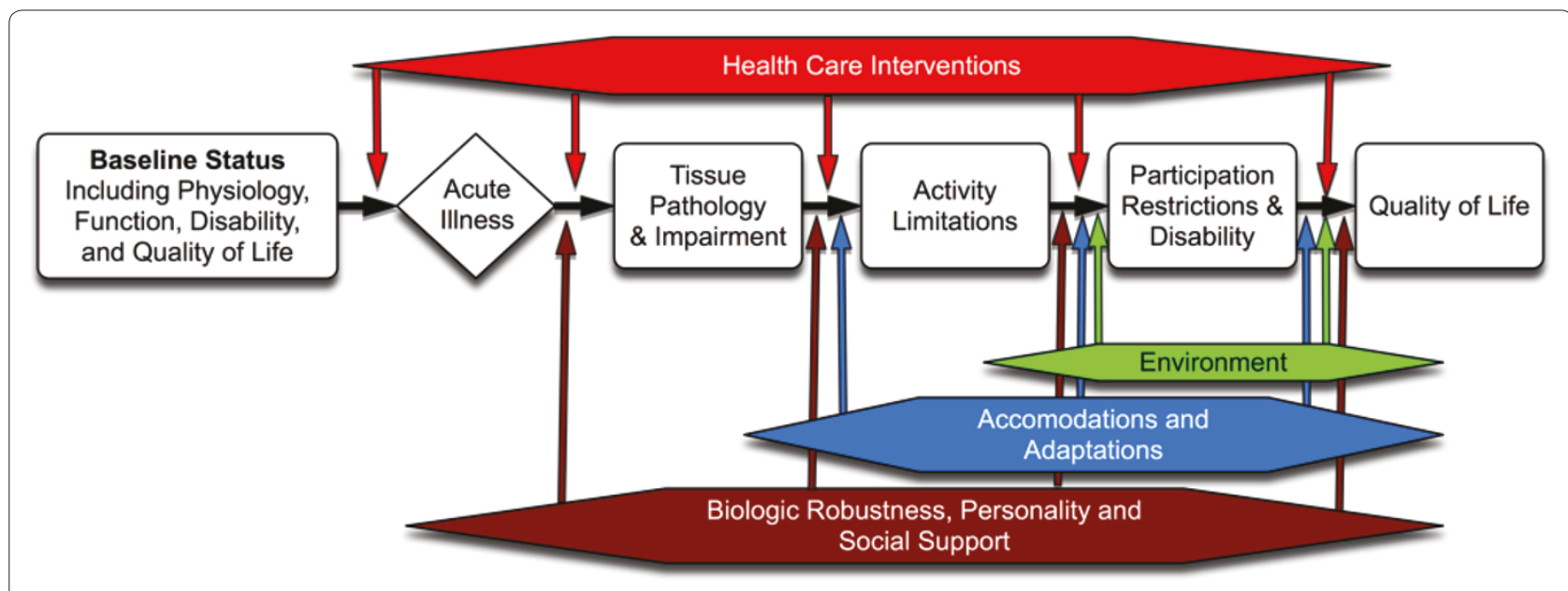

Figure 1. Disablement process model.

disability/quality of life axis of Figure 1. Increasingly, this work has focused on cognitive, psychiatric, and muscular problems as the physiologic basis underlying the longterm problems. Research into first-generation long-term outcomes has defined the frequencies of different sorts of problems among survivors.

The conceptual model of Figure 1 suggests that there are at least two ripe domains for a next generation of research. We should explore variation in patient characteristics and hospitalization characteristics that lead to differences in subsequent outcomes $[8,13]$. But we also need to understand those effect modifiers - particularly those external to the patient - which change the conditional probabilities of an outcome: that is, what are those characteristics which explain why patients with the same physiology have different disability? Such data help us explore not only prevention of adverse long-term outcomes but harm mitigation of whatever irreversible physiologic damage may be done.

There is an almost overwhelming variety of potential effect modifiers one might consider in next-generation long-term outcome studies. A few seem particularly promising. The first is to look at the impact of social support on recovery [14]. We know that families play an essential but challenging role in decision-making in the intensive care unit $[15,16]$. But we have much less evidence to test the plausible and actionable hypothesis that patients discharged into high-social support environments make a more rapid recovery.

Also, we have not taken patients and families seriously enough as actors and partners in their own care. The social science jargon for this would be that we have neglected the agency of patients and families. Rather than waiting passively for assistance from medical professionals, survivors are experimenting with new ways to heal and adapt. How can we learn from those survivors and facilitate their collective wisdom and resilience? How can we crowd-source recovery?

Cuthbertson and colleagues have confirmed the substantial burdens under which survivors labor and have emphasized the resilience and capacity of those survivors. The authors have set the stage for a next generation of research that moves beyond these average effects essential though they are in defining the problem - to leverage the variation in patients' recovery to discover new ways to improve it.

Competing interests

The authors declare that they have no competing interests.

\section{Acknowledgments}

This work was supported by grants K08 HL091249 from the National Institutes of Health and IIR 11-109 from the Department of Veterans Affairs Health Services Research \& Development Service.

\section{Disclaimer}

The views expressed in this article are those of the authors and do not necessarily reflect the position or policy of the Department of Veterans Affairs, the National Institutes of Health, or the US government.

\section{Author details}

'Department of Internal Medicine, University of Michigan, North Campus Research Center, 2800 Plymouth Road, Building 16, Room 332W, Ann Arbor, MI 48109, USA. ${ }^{2}$ Center for Clinical Management Research, Ann Arbor VA, North Campus Research Center, 2800 Plymouth Road, Building 16, Room 332W, Ann Arbor, Ml 48109, USA. ${ }^{3}$ Institute for Social Research, University of Michigan, Ann Arbor, MI, USA. ${ }^{4}$ Department of Medicine, Ann Arbor VA, North Campus Research Center, 2800 Plymouth Road, Building 16, Room 332W, Ann Arbor, MI 48109, USA.

\section{Published: 12 June 2013}

\section{References}

1. Cuthbertson BH, Elders A, Hall S, Taylor J, Maclennan G, McKirdy F, Mackenzie SJ, Scctg And Sics SC: Mortality and quality of life in the five years after severe sepsis. Crit Care 2013, 17:R70

2. Cuthbertson BH, Roughton S, Jenkinson D, Maclennan G, Vale L: Quality of life in the five years after intensive care: a cohort study. Crit Care 2010, 14:R6.

3. Herridge MS, Tansey CM, Matté A, Tomlinson G, Diaz-Granados N, Cooper A, 
Guest CB, Mazer CD, Mehta S, Stewart TE, Kudlow P, Cook D, Slutsky AS, Cheung AM; Canadian Critical Care Trials Group: Functional disability 5 years after acute respiratory distress syndrome. N Engl J Med 2011, 364:1293-1304.

4. Quartin AA, Schein RMH, Kett DH, Peduzzi PN: Magnitude and duration of the effect of sepsis on survival. JAMA 1997, 277:1058-1063.

5. Iwashyna TJ, Cooke CR, Wunsch H, Kahn JM: The population burden of long-term survivorship after severe sepsis among older Americans. J Am Geriatr Soc 2012, 60:1070-1077.

6. Iwashyna TJ, Netzer G, Langa KM, Cigolle C: Spurious inferences about longterm outcomes: the case of severe sepsis and geriatric conditions. Am J Respir Crit Care Med 2012, 185:835-841.

7. Davydow DS, Hough CL, Langa KM, Iwashyna TJ: Depressive symptoms in spouses of older patients with severe sepsis. Crit Care Med 2012, 40:2335-2341.

8. Clermont G, Angus DC, Linde-Zwirble WT, Griffin MF, Fine MJ, Pinsky MR: Does acute organ dysfunction predict patient-centered outcomes? Chest 2002, 121:1963-1971.

9. Iwashyna TJ, Netzer G: The burdens of survivorship: an approach to thinking about long-term outcomes after critical illness. Semin Respir Crit Care Med 2012, 33:327-338.

10. IOM Committee on Disability in America: The Future of Disability in America. Washington, DC: National Academies Press; 2007.

11. lezzoni LI, Freedman VA: Turning the disability tide: the importance of definitions. JAMA 2008, 299:332-334.
12. Freedman VA: Adopting the ICF language for studying late-life disability a field of dreams? J Gerontol A Biol Sci Med Sci 2009, 64:1172-1174; discussion 5-6

13. Lone NI, Walsh TS: Impact of intensive care unit organ failures on mortality during the five years after a critical illness. Am J Respir Crit Care Med 2012, 186:640-647.

14. Cameron Jl, Herridge MS, Tansey CM, McAndrews MP, Cheung AM: Well-being in informal caregivers of survivors of acute respiratory distress syndrome. Crit Care Med 2006, 34:81-86.

15. Sullivan DR, Liu X, Corwin DS, Verceles AC, McCurdy MT, Pate DA, Davis JM, Netzer G: Learned helplessness among families and surrogate decisionmakers of patients admitted to medical, surgical, and trauma ICUs. Chest 2012, 142:1440-1446.

16. Azoulay E, Pochard F, Kentish-Barnes N, Chevret S, Aboab J, Adrie C, Annane D, Bleichner G, Bollaert PE, Darmon M, Fassier T, Galliot R, Garrouste-Orgeas M, Goulenok C, Goldgran-Toledano D, Hayon J, Jourdain M, Kaidomar M, Laplace C, Larché J, Liotier J, Papazian L, Poisson C, Reignier J, Saidi F, Schlemmer B; FAMIREA Study Group: Risk of post-traumatic stress symptoms in family members of intensive care unit patients. Am J Respir Crit Care Med 2005, 171:987-994.

doi:10.1186/cc12717

Cite this article as: Iwashyna TJ, Odden AJ: Sepsis after Scotland: enough with the averages, show us the effect modifiers. Critical Care 2013, 17:148 